ZOOLOGIA 30 (1): 35-42, February, 2013

http://dx.doi.org/10.1590/S1984-46702013000100004

\title{
Use of space by the Neotropical caviomorph rodent Thrichomys apereoides (Rodentia: Echimyidae)
}

\author{
Alex José de Almeida', Melina Maciel F. Freitas \& Sônia A. Talamoni,2 \\ 1 Programa de Pós-graduação em Zoologia de Vertebrados, Pontifícia Universidade Católica de Minas Gerais. Avenida Dom \\ José Gaspar 500, 30535-610 Belo Horizonte, MG, Brasil. \\ 2 Corresponding author. E-mail: talamoni@pucminas.br
}

\begin{abstract}
The objective of this study was to investigate some parameters of the space use by individuals in a population of the hystricognath rodent Thrichomys apereoides (Lund, 1839), using the spool-and-line tracking technique. This technique is useful for investigating characteristics of habitat use by individuals since it allows the mapping of the places where the individuals move. We evaluated three parameters of space use by 34 individuals of $T$. apereoides: 1) The daily home range (DHR) or the area used by individuals in their daily activities, 2) the distance moved on the leaf litter, and 3) the distance moved above ground using twigs, logs and rocks. The analysis of space use on such a small scale allows a better understanding of how individuals perceive and use the available space. The significant effect of age on DHR and the effect of the sex on the movements above ground were observed. Adult males had larger DHRs than adult females and subadults, and adult females showed the lowest displacement above ground. A statistically significant effect of the sex and seasonal period and the interaction between them was also observed on the size of DHRs of adults. During the dry season, females had lower DHRs than males and both females and males moved less on leaf litter in this season. There was no seasonal effect on the movement of males and females above ground, as well as no significant effect of age and sex on the movement of the individuals on leaf litter. We found that individuals responded differently to some aspects of the habitat structure and concluded that the pattern of movement is influenced by the sex and the age of the individuals and may vary according to ecological conditions.
\end{abstract}

KEY WORDS. Caviomorph rodent; daily home range; spacing pattern; spool-and-line.

A commonly studied parameter regarding space use by a population is the variation in size of the home ranges of different individuals or classes of individuals within that population. A number of life history factors have been used to explain this variation among individuals including age, sex, season, breeding season, and population density (MAGNusson et al. 1995, Kelt \& Van Vuren 2001, Endries \& Adler 2005). It has also been shown that the spacing pattern is associated with the social mating system used (ADLER 2011, MAHER \& BURger 2011), with the dispersion in the environment of individuals being strongly influenced by the way they behave in accordance to their needs and their role in their particular mating system (CLUTTON-BRock \& Harvey 1978, GitTleman \& Thompson 1988).

Moreover, several models have been developed to explain the influence of ecological conditions on the social organization of mammals (EMLen \& ORING 1977, OstFeld 1985, Johnson et al. 2002, MACDONALD 1983). It has been shown that different populations of the same species, or even the same population at different times, may vary in their social systems and spacing pattern due to ecological factors (see MAHER \& BURger 2011). Among caviomorph rodents, for example, distribution and availability of food resources, climatic conditions, and preda- tion risk have been correlated with, and used to explain, intraspecific variation in the characteristics of home range and use of space (Adler 1998, 2011, Adrian \& SAChSER 2011, Maher \& BURGER 2011).

Capture-mark-recapture is a classical method employed in studies on space use (Dueser \& Shugart 1979, Lacher \& Alho 1989, Jorgensen \& Demarais 1999). However, this technique provides little information about the movements of individuals (Prevedello et al. 2010), which have their movements interrupted by their capture in live traps. There have been a number of studies on the use of space by several species using the spool-and-line tracking technique (Prevedello et al. 2008, CERBONCINI et al. 2011). This technique allows the calculation of total home range of individuals in the traditional sense (Cerboncini et al. 2011) as well the calculation of the "daily home range" (DHR), resulting from the movement of animals during their normal activities in one night (CUNHA \& VIEIRA 2002, Mendel \& Vieira 2003, Loretto \& Vieira 2005, Delciellos et al. 2006, Almeida et al. 2008, Prevedello et al. 2010). This technique is also useful for investigating other characteristics of habitat use by individuals since it allows the mapping of the places where the individuals move. 
In this study, using the spool-and-line tracking technique, we investigate the influence of sex, age and seasonal period on the space use by individuals of a population of Thrichomys apereoides (Lund, 1839) specifically related with: 1) the area used by individuals in their daily activities (DHR), 2) the distance moved on the leaf litter, and 3) the distance moved above ground using twigs, logs and rocks. The analysis of space use on such a small scale allows a better understanding of how individuals perceive and use the available space.

\section{MATERIAL AND METHODS}

The study was conducted at Cauaia farm $\left(19^{\circ} 28^{\prime} 57^{\prime \prime} \mathrm{S}\right.$, $44^{\circ} 00^{\prime} 50^{\prime \prime} \mathrm{W}$ ), in an area (364 ha) of semideciduous forest, located in the protected area (Área de Proteção Ambiental) of Lagoa Santa Karst, in the municipality of Matozinhos, state of Minas Gerais, Brazil. The Cauaia farm itself has $20 \%$ of its area under preservation and consists of rocky outcrops covered with semideciduous and deciduous forests, and with cerrado in the immediate surroundings. The region is under the phytogeographic domains of the Atlantic Forest and Cerrado (Savannas) (IBGE 2004) and the climate of the region is classified as humid tropical savannah, with a rainy season from October to March and a dry season from April to September (SÁ Jr et al. 2012). The average air temperature in the region is around $23^{\circ} \mathrm{C}$ (BERBERT-BORn 2002).

The species studied was the New World hystricognath rodent $T$. apereoides, an echimyid that occurs in areas of savanna and forests, where it uses crevices in the rocks for shelter, protection, and nesting; it is terrestrial and semi-arboreal, diurnal and nocturnal; with a diet that includes leaves, twigs, berries, seeds, fruits and insects (STreilein 1982a, Reis \& PessôA 2004). The species occurs in the states of Minas Gerais, Goiás and Bahia (Bonvicino et al. 2008).

We captured animals for six consecutive days each month from August, 2008 to July, 2009. One hundred forty-three traps $(15 \times 15 \times 30 \mathrm{~cm})$ were set in a grid with traps $20 \mathrm{~m}$ apart and arranged in 15 parallel rows, covering an area of 4.7 ha. The total capture effort was 8,580 traps-nights. Traps were baited with a mixture of peanut butter, sardines, and bananas. Each point of capture was received in a trap on the ground. The traps were checked in the morning and the bait was changed when necessary. The information about captured individuals including sex, approximate age, and body mass were recorded monthly. Each captured animal was individually marked using numbered ear tags (National Band Tag and Company). Thirty-four animals were tagged, sexed, and placed in one of two age classes; either subadult and sexually immature (150$180 \mathrm{~g}$ ), or adult and probably sexually mature (> 180-350 g) (Thompson 1985, Roberts et al. 1988, Teixeira et al. 2005).

Each marked individual received a tracking spool (4 g, line length of $400 \mathrm{~m}$ ) (Boonstra \& Craine 1986), which was wrapped in plastic wrap and tape, then glued to the back of the animal with cyanoacrylate glue (Superbonder ${ }^{\circledR}$ ) (RYAN et al. 1993, Key \& Woods 1996, Cunha \& Vieira 2002). The line of the spool was tied to an object at the point of release of each animal. After the animal was left to move freely, the line was mapped by measuring the linear distance between two turning points using a measuring tape, and the azimuth was obtained for all the turning points of the line formed by the animal's movements. Only spools with more than $35 \mathrm{~m}$ line mapped were considered for analysis (LoRETTo \& Vieira 2005). For data analysis the initial $20 \mathrm{~m}$ were excluded which presumably reflected escape behavior (Pizzuto et al. 2007).

The values of the azimuths and the distances between the turning points for each tracked animal were transformed into Cartesian coordinates $(\mathrm{x}, \mathrm{y})$, which were used to calculate the daily home range (DHR), using 100\% of the minimum convex polygon (MCP) (Mohr 1947, Stickel 1954), and to quantify the distance moved on the litter (LIU) and above ground (walking over logs, branches, roots, rocks - AGR). The vertical displacements also were included in this measure. The MCP method has been criticized as an estimate of the size of an animal's home range (BÖRGER et al. 2006), but it is simple to use and is not constrained by underlying statistical assumptions (HarLess et al. 2010). The layout of each route and the corresponding area of the polygon were performed using the software 1.0.4 Biotas alpha.

General Linear Models (GLM) were used for the analysis of the intra-population variation of the log-transformed variables DHR, LIU and AGR as functions of the factors of sex, age class, seasonal period, and their interaction (LiNDSEY 1997). Tukey's test for post hoc comparisons was used when needed. We performed the models: 1) analysis of the effects of sex, age class, and interaction between them, on DHR, on the movement on litter (LIU), and on the movement above ground (AGR); 2) analysis of the effects sex, seasonal period and interaction between them on DHR, on the movement on litter (LIU), and on the movement above ground (AGR).

All of the parameters analyzed correlated significantly with the total line-distance mapped. Thus, the total line-distance mapped was initially included in the models as an additional variable (covariate) (DRAPER \& SMITH 1998). In the absence of a significant interaction between the covariate and the factors to be tested, the effect of total line-distance mapped was disregarded and the adjustment of the model was executed again (LORETTO \& VIEIRA 2005). Many individuals were tracked during both seasons, thus, to analyze the effect of seasonality on the sizes of the DHR, these individuals were represented by the data from one spool obtained in each climatic season. For seasonality analysis, data obtained from adults only was used in order to avoid any influence of age in this analysis due to a possible seasonal recruitment of subadults. In the analysis of movement on leaf litter and above ground, we used data from the spools used in the first capture of individuals in each monthly session of sampling, thus, there were monthly repetitions for some individuals. 


\section{RESULTS}

All of the parameters analyzed correlated significantly with the total line-distance mapped (Pearson correlation, DRH: $\mathrm{r}=0.735, \mathrm{p}<0.05$; LIU: $\mathrm{r}=0,820, \mathrm{p}<0.05$ AGR: $\mathrm{r}=0,665, \mathrm{p}<$ 0.05). Therefore, the total line-distance mapped was included in the models (GLM analysis) as an additional variable (covariate); in this model there was an absence of a significant result ( $p>0.05$ ), and the effect of total line-distance mapped on the factors tested was disregarded.

The general linear models revealed a significant effect of age on DHR as well as the effect of the sex on AGR (Table I). Adult males had greater DHRs than adult females and subadults (Fig. 1), and adult females showed the lowest displacement above ground (Fig. 5). There was no significant effect of the age and sex on the movement of individuals on leaf litter (Table I, Fig. 3).

There was a statistically significant effect of the sex and seasonal period and the interaction between them on the size of DHRs of adults (Table I). A seasonal effect was also observed on LIU of adults (Table I). Females had lower DHRs than males during dry season (Fig. 2), and both females and males moved less on leaf litter in the dry season (Fig. 4). There was no seasonal significant difference between the movement of males and females above ground (Fig. 6).

\section{DISCUSSION}

In this study, differences in the size of DHRs due to age were observed. Adult males had larger DHRs than subadults. This kind of difference has been attributed to the differing energy requirements among different individuals (MARQUET et al. 2005, Almeida et al. 2008, Vieira \& CunHa 2008). However, the DHR expresses the spacing between the individuals and their daily movements, which can be viewed primarily as a result of hierarchical, demographic and economic processes (PriotTo et al. 2004, Rehmeier et al. 2004, Skvarla et al. 2004, Mitchell \& Powell 2012). Females had smaller DHRs and movement on the litter during the dry season, as well as the lowest movements above ground. Data from animals kept in captivity (TeixeIra et al. 2005), and evidence obtained in the field for this population in another study, in which there was a greater recruitment of subadult individuals in the rainy season (A.J. Almeida, unpub. data), indicate that T. apereoides reproduce mainly during the dry season. If this is indeed the reproductive pattern, presumably then smaller DHRs in the dry season, as well as other parameters, might be a consequence of female reproductive activities, because more energy would need to be allocated to reproduction (mating, feeding and care of pups) (GitTLEman \& THOMPson 1988), at the expense of energy expended in movements. Therefore, it is expected that there is some relationship

Table I. Effect of sex, age class, seasonal period, and total amount of mapped line on the daily home range size (DHR), and movements (LIU, AGR) of Thrichomys apereoides. (a) Including the interactions between the factors and the probable effects of the interaction between these factors and the amount of mapped line, $\left(^{b}\right)$ including the interactions between the factors and excluding interactions not found to be significant with the amount of mapped line. (DHR) Daily home range, (LIU) Movements on leaf litter, (AGR) movements above ground, $\left(r^{2}\right)$ coefficient obtained for adjusted model.

\begin{tabular}{|c|c|c|c|c|c|c|c|c|c|c|c|c|}
\hline \multirow{2}{*}{ Factors } & \multicolumn{2}{|c|}{$\mathrm{DHR}^{\mathrm{a}}$} & \multicolumn{2}{|c|}{$\mathrm{DHR}^{\mathrm{b}}\left(\mathrm{r}^{2}=0.60\right)$} & \multicolumn{2}{|c|}{ LIU $^{a}$} & \multicolumn{2}{|c|}{$\operatorname{LIU}^{\mathrm{b}}\left(\mathrm{r}^{2}=0.67\right)$} & \multicolumn{2}{|c|}{$\mathrm{AGR}^{\mathrm{a}}$} & \multicolumn{2}{|c|}{$\mathrm{AGR}^{\mathrm{b}}\left(\mathrm{r}^{2}=0.57\right)$} \\
\hline & $\mathrm{F}$ & $\mathrm{p}$ & $\mathrm{F}$ & $p$ & $\mathrm{~F}$ & $p$ & $\mathrm{~F}$ & $\mathrm{p}$ & $\mathrm{F}$ & $P$ & $\mathrm{~F}$ & $p$ \\
\hline Sex & 0.020 & 0.873 & 0.02 & 0.870 & 0.070 & 0.783 & 1.310 & 0.250 & 0.100 & 0.113 & 4.420 & 0.003 \\
\hline Age class & 0.480 & 0.340 & 11.65 & 0.009 & 2.450 & 0.121 & 1.179 & 0.280 & 0.430 & 0.511 & 0.150 & 0.695 \\
\hline Mapped line & 52.030 & 0.000 & 128.09 & 0.000 & 91.550 & 0.000 & 178.000 & 0.000 & 49.030 & 0.000 & 70.150 & 0.000 \\
\hline Sex*Age class & 0.270 & 0.600 & 0.03 & 0.858 & 0.000 & 0.928 & 0.107 & 0.744 & 0.000 & 0.960 & 0.630 & 0.426 \\
\hline Sex*Mapped line & 0.110 & 0.735 & - & - & 0.940 & 0.334 & - & - & 2.050 & 0.155 & - & - \\
\hline Age class*Mapped line & 1.180 & 0.888 & - & - & 1.700 & 0.194 & - & - & 1.020 & 0.315 & - & - \\
\hline Sex*Age class*Mapped line & 0.540 & 0.462 & - & - & 0.020 & 0.887 & - & - & 0.030 & 0.858 & - & - \\
\hline Sex & 1.200 & 0.277 & 6.42 & 0.013 & 0.592 & 0.444 & 0.498 & 0.482 & 0.162 & 0.687 & 0.973 & 0.327 \\
\hline Seasonal period & 0.167 & 0.683 & 15.24 & 0.000 & 0.841 & 0.362 & 4.008 & 0.049 & 1.107 & 0.296 & 0.443 & 0.507 \\
\hline Mapped line & 68.970 & 0.000 & 142.78 & 0.000 & 66.68 & 0.000 & 90.690 & 0.000 & 18.310 & 0.000 & 43.285 & 0.000 \\
\hline Sex*Seasonal period & 0.209 & 0.648 & 7.66 & 0.007 & 0.006 & 0.814 & 0.623 & 0.432 & 2.439 & 0.123 & 0.085 & 0.770 \\
\hline Sex*Mapped line & 1.376 & 0.245 & - & - & 0.049 & 0.824 & - & - & 1.886 & 0.174 & - & - \\
\hline Seasonal period*Mapped line & 0.111 & 0.739 & - & - & 1.753 & 0.190 & - & - & 0.487 & 0.487 & - & - \\
\hline Sex*Seasonal period*Mapped line & 2.429 & 0.124 & - & - & 0.116 & 0.733 & - & - & 3.290 & 0.070 & - & - \\
\hline
\end{tabular}

* Interaction between factors. 

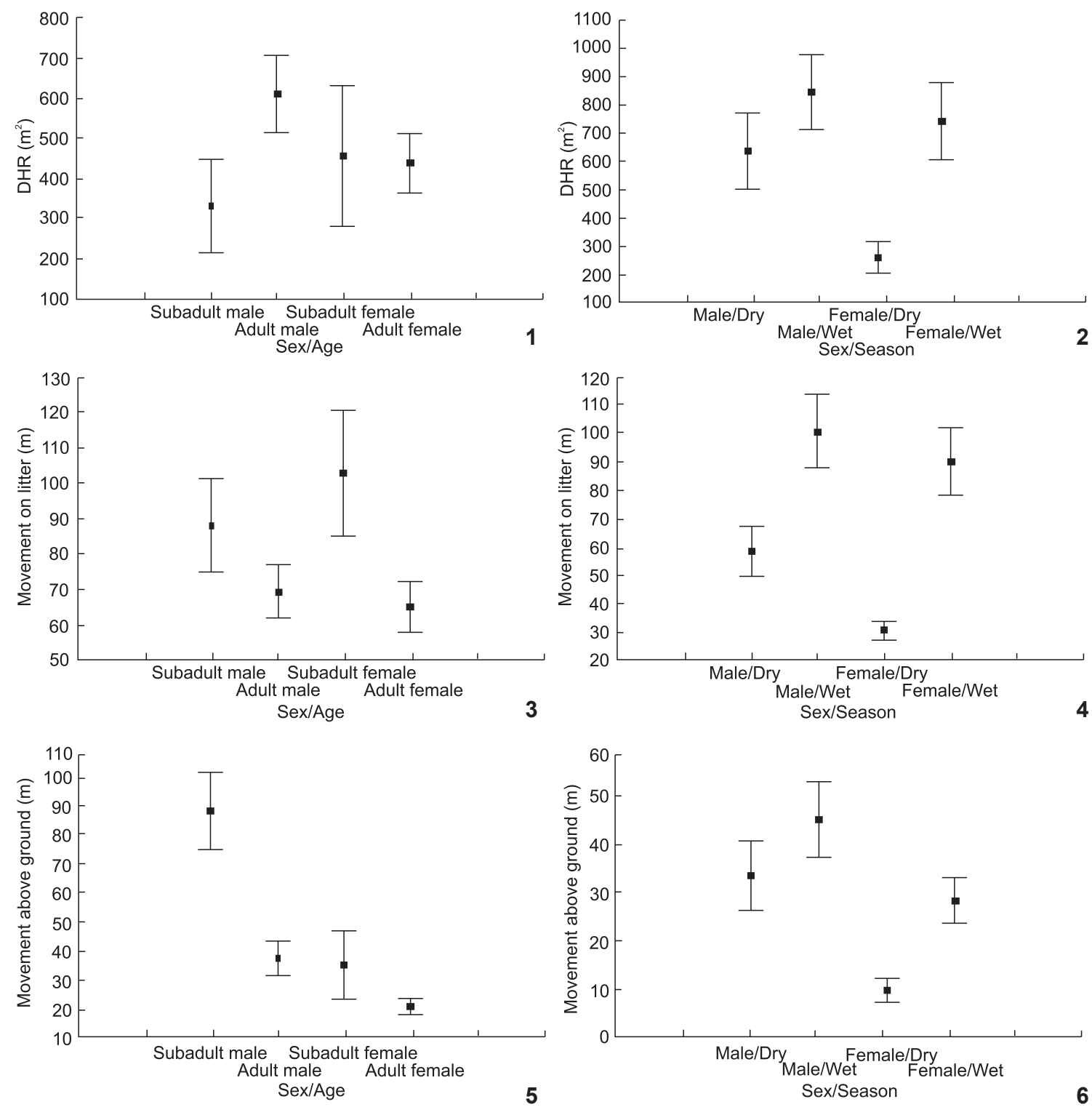

Figures 1-6. Mean values and respectively standard error of parameters of space use by Thrichomys apereoides obtained with the spooland-line tracking technique for individuals living in the forest of Cauaia farm between the months August 2008 and July 2009. Daily Home Range (DHR) presented by (1) sex and age class, and (2) sex and seasonal period. Movements on leaf litter (LIU) presented by (3) sex and age class, and (4) sex and seasonal period. Movements above ground (AGR) presented by (5) sex and age class, and (6) sex and seasonal period.

between the activities of females with the availability of food resources in this period.

The availability of food resources has been considered as one of the most important factors that influence the pattern of use of space by mammals (AdLer 2011, Adrian \& SaChSER 2011, Maher \& Burger 2011). Depending on the spatial and temporal distribution of resources (ADLER 2011), in order to maximize their fitness, female rodents tend to be territorial when food resources are scattered with lower renewal rates, while the males are distributed according to the space used by the females (OSTFeld 1985). Consequently, the spacing pattern of individuals has often been investigated in order to determinate the mating system of species (EMLen \& OrIng 1977, Ostfeld 1985, Gaulin \& Fitzgerald 1988, Maher \& Burger 2011). 
A pattern that has been found for some species of rodents based on space use is the polygyny (Gaulin \& FitzGERALD 1988, Ostreld 1990). This mating system was attributed to $T$. apereoides (Streilein 1982b, Thompson 1985), and for some hystricognath (Bergallo 1995, Bergallo \& Magnuson 1999) and Sigmodontinae (Bonaventura et al. 1992, Heinemann et al. 1995, Gentile et al. 1997, Bergallo \& Magnuson 1999, Pires et al. 2010) rodents. In this system, the males tend to travel greater areas in their search for females during the reproductive period, and the spacing patterns of males will be determined directly by the spacing of females rather than by resource distribution; in turn the females depending on resources distributed in patches tend to exhibit territorial tendencies and sometimes they are faced with the need to defend resources (OstFeld 1990).

Territorial trends for females were found for other hystricognath species such as Trinomys iheringi (BERGALLo 1995) and T. moojeni (CORDeiro Jr \& TALAmoni 2006). In addition, reproductive activity was observed during the dry season for these two Trinomys species. It is important to note that the studied echimyid occurs in area with pronounced seasonality, particularly related to the amount of rainfall (SÁ JR et al. 2012). The rain scarcity normally leads to a lower availability of fruit and insects during the dry season (SMIthe 1982, Charles-Dominique 1983, Bergallo \& Magnusson 1999, Stenvenson et al. 2000). Therefore, it is expected that food resources that commonly are locally distributed in temporal and spatial patches (BERGallo \& MaGNUSSON 1999, Stenvenson et al. 2000) can cause some influence over the movements of $T$. apereoides in this season. It was observed that for species that reproduce in a time of lower food availability, females may show a pattern of smaller displacement. In mammals, the greater parental investment lies with the females (Trivers 1972, GitTleman \& Thompson 1988); therefore, the females tend to conserve energy expended in movement, establishing lower home ranges (LoRetTo \& VieIRA 2005). In Panamá, for the spiny rat Proechimys semispinosus (Tomes, 1860), ENDRIEs \& ADLER (2005) observed that individuals of both the sexes had larger home ranges during the rainy season. Furthermore, there was a positive relationship between home-range size and the number of fruiting trees within a home range. In contrast, no female spiny rats and only two of seven males captured during the dry season were in reproduction condition.

Alternatively, it has sometimes been observed that food shortages may force the individuals to expand their foraging areas and their home ranges (SLADE \& SwiHART 1983, Gaulin \& FitzGerald 1988, Passamani 2000). We did not observe this phenomenon in this study, since both males and females did not significantly expanded their areas during the dry season, instead females showed a reduction in their movements, and the males showed DHRs always larger than females, this being the expected result assuming that T. apereoides is a polygynous species (STREILEIN 1982b).

In addition to the search for food and reproductive strategies, the predation pressure is recognized as having a strong influence on the characteristics of space use by various species of small mammals, directing their path choices during their movements (Holbrook 1979, Garshelis 2000, GeTz et al. 2005). The risk of predation can limit the distance traveled by prey, thus reducing the home range of individuals as well as the pattern of overlapping home ranges among individuals (Yunger 2004, Petorell et al. 2011). In this study, the adults of both sexes showed a significantly lower displacement on the leaf litter during the dry season. Assuming that differences occur in the sounds produced by movements of individuals on the leaf litter during the dry and rainy seasons, these animals might be avoiding movement on this type of substrate during the dry season because the sound produced could attract the attention of predators. However, only studies designed with the specific objective to test these hypotheses could show conclusively the influence of predation on the distance traveled by the individuals on the litter and the choice of specific paths by individuals.

It was observed that individuals of all age classes presented movement above ground but subadult males were more frequent. This result may indicate that subadult males utilize smaller areas, but more intensively, incorporating the use of the vertical stratum in their activities, as observed for some subadult marsupials (CUNHa \& VieIRa 2005, Almeida et al. 2008). Subadult females use larger areas, but less intensively, moving predominantly on the litter.

In this study, we concluded that the pattern of movement is influenced by the sex and age of the individuals and that it may vary according to ecological conditions, especially those related to seasonal variations. Further studies should be directed to test separately the effect of the sex and the age and the environmental conditions on the DHR and movements of T. apereoides.

\section{ACKNOWLEDGMENTS}

We thank Marcus V. Vieira, Adriano P. Paglia and Gisele Lessa for their suggestions, Miguel Assis for the support and information he exchanged, and Andrew Linghorn for the English revision. Our gratitude goes to José Hein and all the residents and staff of the fazenda Cauaia. We thank CAPES for scholarship to A.J.A, and FIP PUC Minas for financial support. This study had the capture license 10807-2 from Chico Mendes Institute for Biodiversity Conservation (ICMBio).

\section{LITERATURE CITED}

ADLER, G.H. 1998. Impacts of resource abundance on populations of a tropical forest rodent. Ecology 79: 242-254.

AdLer, G.H. 2011. Spacing patterns and social mating systems of echimyid rodents. Journal of Mammalogy 92: 31-38.

Adrian, O. \& N. SACHSER. 2011. Diversity of social and mating systems in cavies: a review. Journal of Mammalogy 92: 39-53. 
Almeida, A.J.; C.G. Torquetti \& S.A. Talamoni. 2008. Use of space by neotropical marsupial Didelphis albiventris (Didelphimorphia: Didelphidae) in an urban forest fragment. Revista Brasileira de Zoologia 25: 214-219.

Berbert-Born, M. 2002. Carste de Lagoa Santa, MG: berço da paleontologia e da espeleologia brasileira, p. 415-430. In: C. Schobbenhaus; D.A. Campos; E.T. Queiroz; M. Winge \& M. BERBERT-Born (Eds). Sítios geológicos e paleontológicos do Brasil. Rio de Janeiro, Departamento Nacional de Produção Mineral (DNPM), Serviço Geológico do Brasil (CPRM).

Bergallo, H.G. 1995. Comparative life-history characteristics of two species of rats, Proechimys iheringi and Oryzomys intermedius, in an Atlantic forest of Brasil. Mammalia 59: 51-64.

Bergallo, H.G. \& W.E. Magnusson. 1999. Effects of climate and food availability on four rodent species in southeastern Brazil. Journal of Mammalogy 80: 472-486.

Bonaventura, S.M.; F.O. Kravetz \& O.V. Suarez. 1992. The relationship between food availability, space use and territoriality in Akodon azarae (Rodentia, Cricetidae). Mammalia 56: 407-417.

Bonvicino, C.R.; J.A. de Oliveira \& P.S. D'Andrea. 2008. Guia dos roedores do Brasil, com chaves para gêneros baseadas em caracteres externos. Rio de Janeiro, Centro Pan-americano de Febre Aftosa - OPAS/OMS, 120p.

Boonstra, R. \& T.M. Craine. 1986. Natal nest location and small mammal tracking with a spool and line technique. Canadian Journal of Zoology 64: 1034-1036.

Börger L.; N. Franconi; G. De Michele; A. Gantz; F. Meschi; A. Manica; S. Lovari \& T. Coulson. 2006. Effects of sampling regime on the mean and variance of home range size estimates. Journal of Ecology 75: 1393-1405.

Cerboncini, R.A.S.; M. Passamani \& T.V. Braga. 2011. Use of space by the black-eared opossum Didelphis aurita in a rural area in southeastern Brazil. Mammalia 75: 287-290.

Charles-Dominique, P. 1983. Ecology and social adaptations in didelphid marsupials: comparisons with eutherian of similar ecology. p. 395-420. In: J.F. EisenberG \& D.G. KleimAn (Eds). Advances in the study of Mammalian Behavior. Shippennshurg, Special Publication \#7, American Society of Mammalogists.

Clutton-Brock, T.H. \& P.H. Harvey. 1978. Mammals, resources and reproductive strategies. Nature 273: 191-195.

Cordeiro-Júnior, D. A. \& S. A. Talamoni. 2006. New data on the life history and occurrence of spiny rats Trinomys moojeni (Rodentia: Echimyidae), in Southeastern Brazil. Acta Theriologica 51: 1-6.

Cunha, A \& M.V. Vieira. 2002. Support diameter, incline, and vertical movements of four didelphid marsupials in the Atlantic Forest of Brazil. Journal of Zoology 258: 419-426.

Cunha, A. \& M.V. Vieira. 2005. Age, season, and arboreal movements of the opossum Didelphis aurita in an Atlantic rain forest of Brazil. Acta Theriologica 50: 551-560.
Delciellos, A.C.; D. Loretto \& M.V. Vieira. 2006. Novos métodos no estudo da estratificação vertical de marsupiais neotropicais. Oecologia Brasiliensis 10: 135-153.

Draper, N.R. \& H.A. Smith. 1998. Applied Regression Analysis. New York, John Wiley \& Sons Incorporation, III + 705 p.

Dueser, R.D. \& H.H. Shugart. 1979. Niche Pattern in Forest-floor in Small Mammal Fauna. Ecology 60: 108-118.

EmLen, S.T. \& L.W. Oring. 1977. Ecology, sexual selection and the evolution of mating systems. Science 197: 215-23.

Endries, M.J. \& G.H. AdLER. 2005. Spacing patterns of a tropical forest rodent, the spiny rat (Proechimys semispinosus), in Panamá. Journal of Zoology 265: 147-155.

Garshelis, D.L. 2000. Delusions in habitat evaluation: measuring use, selection, and importance, p.111-164. In: L. BOITANI \& T.K. Fuller (Eds). Research Techniques in Animal Ecology: Controversies and Consequences. New York, Columba University Press.

Gaulin, J.C. \& R.W. Fitzgerald. 1988. Home range size as a predictor of mating systems in Microtus. Journal of Mammalogy 69: 311-319.

Gentile, R.; P.S. D'Andrea \& R. Cerqueira. 1997. Home ranges of Philander frenata and Akodon cursor in a Brazilian restinga (coastal shrubland). Mastozoologia Neotropical 4: 105-112.

Getz, L.L.; M.K. Oli; J.E. Hofmann; B. McGuire \& A. Ozgul. 2005. Factors influencing movement distances of two species of sympatric voles. Journal of Mammalogy 86: 647-654.

Gittleman, J.L. \& S.D. Thompson. 1988. Energy allocation in mammalian reproduction. American Zoologist 28: 863-875.

Harless, M.L.; A.D. Walde; D.K. Delaney; L.L. Pater \& W.K. Hayes. 2010. Sampling considerations for improving home range Estimates of desert tortoises: effects of estimator, Sampling regime, and sex. Herpetological Conservation and Biology 5 (3): 374-387.

Heinemann, K.M.; N. Guthmann; M. Lozada \& J.A. Monjeau. 1995. Area de actividad de Abrothrix xantorhinus (Muridae, Sigmodontinae) e implicancias para su estratégia reproductiva. Mastozoologia Neotropical 2: 23-30.

Holвrook, S. 1979. Vegetation affinities, arboreal activity, and coexistence of three species of rodents. Journal of Mammalogy 60: 528-542.

IBGE. 2004. Mapa de vegetação do Brasil. Rio de Janeiro, Instituto Brasileiro de Geografia e Estatística, escala 1:5000000.

Johnson, D.D.P; R. Kays; P.G. BlackWell \& D.W. Macdonald. 2002. Does the resource dispersion hypothesis explain group living? Trends in Ecology \& Evolution 17: 563-570.

Jorgensen, E.E. \& S. Demarais. 1999. Spatial scale dependence of rodent habitat use. Journal of Mammalogy 80: 421-429.

Kelt, D.A. \& D.H. van Vuren. 2001. The ecology and macroecology of mammalian home range area. American Naturalist 157: 637-45.

Key, G.E. \& R.D. Woods. 1996. Spool-and-line studies on the behavioural ecology of rats (Rattus spp.) in the Galápagos Islands. Canadian Journal of Zoology 74: 733-737. 
LACher Jr, T.E. \& C.J.R. Alho. 1989. Microhabitat use among small mammals in the Brazilian Pantanal. Journal of Mammalogy 70: 396-401.

LINDSEY, J.K. 1997. Applying Generalized Linear Models. New York, Springer-Verlag, 255p.

Loretto, D. \& M.V. Vieira. 2005. The effects of reproductive and climatic seasons on movements in the black-eared opossum (Didelphis aurita Wied-Neuwied, 1826). Journal of Mammalogy 86: 287-293.

MACDONALD, K. 1983. Production, social controls, and ideology: toward a sociobiology of the phenotype. Journal of Social and Biological Structures 6: 297-317.

Magnusson, W.E.; A.L. Francisco \& T.M. Sanaiotti. 1995. Home range size and territoriality in Bolomys lasiurus (Rodentia: Muridae) in an Amazonian savanna. Journal of Tropical Ecology 11: 179-188.

MAHER, C.R. \& J.R. Burger. 2011. Intraspecific variation in space use, group size, and mating systems of caviomorph rodents. Journal of Mammalogy 92: 54-64.

Marquet, P.A.; R.A. Quiñones; A.S. Abades; F. Labra; M. Tognelli; M. ARim \& M. Rivadeneira. 2005. Scaling and Power-laws in ecological systems. The Journal of Experimental Biology 208: 1749-1969.

Mendel, S.M. \& M.V. Vieira. 2003. Movement distances and density estimation of small mammals using the spool-andline technique. Acta Theriologica 48: 298-300.

Mitchell, M.S. \& R.A. Powell. 2012. Foraging optimally for home ranges. Journal of Mammalogy 93: 917-928.

Moнr, C.O. 1947. Table of equivalent populations of North American small mammals. American Midland Naturalist 37: 223-249.

OstFeLd, R.S. 1985. Limiting resources and territoriality in microtine rodents. American Naturalist 126: 1-15.

Ostfeld, R.S. 1990. The ecology of territoriality in small mammals. Tends in Ecology \& Evolution 5: 411-415.

Passamani, M. 2000. Análise da comunidade de marsupiais em Mata Atlântica de Santa Teresa, Espírito Santo. Boletim do Museu de Biologia Mello Leitão 11: 215-228.

Pettorelli, N.; T. Coulson; S.M. Durant \& J.M. Gaillard. 2011. Predation, individual variability and vertebrate population dynamics. Oecologia 167: 305-314.

Pires, A.S.; F.A.S. Fernandes; B.R. Feliciano \& D. Freitas. 2010. Use of space by Necromys lasiurus (Rodentia, Sigmodontinae) in a grassland among Atlantic Forest fragments. Mammalian Biology 75: 270-276.

Pizzuto, T.A.; G.R. Finlayson; M.S. Crowther \& C.R. Dickman. 2007. Microhabitat use by the brush-tailed bettong (Bettongia penicillata) and burrowing bettong (B. lesueur) in semiarid New South Wales: implications for reintroduction programs. Wildlife Research 34: 271-279.

Prevedello, J.A.; A.F. Mendonça \& M.V. Vieira. 2008. Uso do espaço por pequenos mamíferos: uma análise dos estudos realizados no Brasil. Oecologia Brasiliensis 12: 610-625.
Prevedello, J.A.; R.G. Rodrigues \& E.L.A. Monteiro-Filho. 2010. Habitat selection by two species of small mammals in the Atlantic Forest Brazil: Comparing results from live trapping and spool-and-line tracking. Mammalian Biology 75: 106114.

Priotto, J.; A. Steinmann; C. Provensal \& J. Polop. 2004. Juvenile dispersal in Calomys venustus (Muridae: Sigmodontinae). Acta Oecologica 25: 205-210.

ReIs, S.F. \& L.M. PEsSÔA. 2004. Thrichomys apereoides. Mammalian Species 727: 1-8.

Rehmeier, R.L.; G.A. Kaufman \& D.W. Kaufman. 2004. Longdistance movements of the deer mouse in tall grass prairie. Journal of Mammalogy 85: 562-568.

RoberTS, M.S.; K.V. ThOMPSOn \& J.A. CRANFORD. 1988. Reproduction and growth in captive punaré (Thrichomys apereoides Rodentia: Echimyidae) of the Brazilian Caatinga with reference to the reproductive strategies of the Echimyidae. Journal of Mammalogy 69: 542-551.

Ryan, J.M.; G.K. Creighton \& L.H. Emmons. 1993. Activity patterns of two species of Nesomys (Muridae: Nesomyinae) in a Madagascar rain forest. Journal of Tropical Ecology 9: 101-107.

Sá Jr, A.; L.G. Carvalho; F.F. Silva \& M.C. Alves. 2012. Application of the Köppen classification for climatic zoning in the state of Minas Gerais, Brazil. Theoretical and Applied Climatology 108: $1-7$.

Skvarla, J.L.; J.D. Nichols; J.E. Hines \& P.M. Waser. 2004. Modeling interpopulation dispersal by banner-tailed kangaroo rats. Ecology 85: 2737-2746.

Slade, N.A. \& R.K. Swihart. 1983. Home range indices for the hispid cotton rat (Sigmodon hispidus) in northeastern Kansas. Journal of Mammalogy 64: 580-590.

SMithe, N. 1982. The seasonal abundance of night-flying insects in a neotropical forest, p. 319-318. In: E.G. LeIGH, A.S. RAND \& D.M. Windsor (Eds). The ecology of a tropical Forest: Seasonal Rhythms and Long Term Changes. Washington, D.C., Smithsonian Institute Press.

Stenvenson, P.R.; M.J. Quiñones \& J.A. Ahumada. 2000. Influence of fruit availability on ecological overlap among four Neotropical primates at Tinigua National Park, Colombia. Biotropica 32: 533-544.

STICKEL, L.F. 1954. A comparison of certain methods of measuring ranges of small mammals. Journal of Mammalogy 35: 115.

StREILEIN, K.E. 1982a. Ecology of small mammals in the semiarid Brazilian Caatinga: I. Climate and faunal composition. Annals of Carnegie Museum 51: 79-107.

Streilein, K.E. 1982b. Ecology of small mammals in the semiarid Brazilian Caatinga: V. Agonistic behavior and overview. Annals of Carnegie Museum 51: 345-369.

Teixeira, B.R.; A.L.R. Roque; S.C. Barreiros-GómeZ; P.M. Borodin; A.M. JANSEN \& P.S. D'ANDREA. 2005. Maintenance and breeding of Thrichomys (Trouessart, 1880) (Rodentia: Echimyidae) in captivity. Memórias do Instituto Oswaldo Cruz 100: 627-630. 
Thompson, K.T. 1985. Social play in the South American punaré (Thrichomys apereoides): a test of play function hypotheses. Blacksburg, Virginia Polytechnic Institute and State University, 120p.

Trivers, R.L. 1972. Parental investment and sexual selection, p. 136-179. In: B. Campbell (Ed). Sexual selection and the descent of man 1871-1971. Chicago, Aldine Publishing
Company.

Vieira, M.V. \& A.A. CunHa. 2008. Scaling body mass and use of space in three species of marsupials in the Atlantic Forest of Brazil. Austral Ecology 33: 8720-879.

YUNGER, J.A. 2004. Movement and spatial organization of small mammals following vertebrate predator exclusion. Oecologia 139: 647-654.

Submitted: 16.XI.2011; Accepted: 27.X.2012.

Editorial responsibility: Walter A.P. Boeger

ZOOLOGIA 30 (1): 35-42, February, 2013 